\title{
Thai Canal and Malacca straits: Complementing or competing stratagem for trade development in South East Asia
}

\section{Jagan Jeevan (D), Nurul Haqimin Mohd Salleh $\mathbb{D}^{\mathbb{B}}$, Mohamad Rosni Othman}

Universiti Malaysia Terengganu

21030, Kuala Nerus, Terengganu, Malaysia

Malaysian Logistics \& Transport Centre (Maltrac), School of Maritime Business and Management

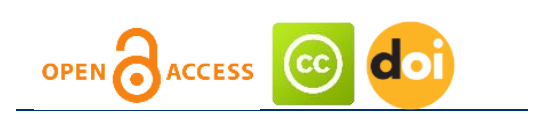

\section{Article history:}

Received: June 29, 2018

1st Revision: August 5, 2018

Accepted: October 19, 2018

\section{DOI:}

10.14254/jsdtl.2018.3-2.2

\begin{abstract}
About 94.8 per cent of Malaysian trade is depending on collective inter/intra-regional maritime networks. Straits of Malacca is an important strait and the only strait that connecting Indian Ocean and South China Sea which contributes to the nation's economic growth significantly. This strait plays a key character to enable the trade connection between east and west of the globe. In average, about 63,000 different types of vessels passing through the strait per year and the number of the vessels keep accelerating every year. Conversely, the introduction of Thai Canal to detour the trade voyage between Indian Ocean to South China Sea is expecting to reduce about three to four days journey time between these two passages. Although the development of this canal is predicted to provide substantial benefits to shipping lines, the grey area or disadvantages change to implications of this canal need to be explored especially on Malaysian trade and infrastructure. Therefore, a qualitative approach has been employed to achieve the aim of this paper. Face-to-face interviews with experts from various agencies had been conducted to gather information on the impact of Thai Canal on Malaysian trade and infrastructure. The outcome of this paper indicates that the implication of Thai Canal reduces the productivity of Malaysian seaports, transformation of seaports in northern region as a major hub of the nation, enforcing equal regional development between west and east coast Malaysia and administering dramatic progress on multimodalism in each state. The outcome of this research is important as an input for the preparation of Malaysian seaport system due to any significant changes in the trade route. Although, the development of Thai Canal reduce the overdependence on Malacca Straits, the impact of this this new canal will affects the trade performance of this region. Hence, this paper is significant to understand the implications that might occur to this nation due to dynamism of maritime logistics.
\end{abstract}

Keywords: Canal, implications, Malaysia, seaport system, trade, infrastructure, sustainable development.

Corresponding author: Jagan Jeevan

E-mail: jagan@umt.edu.my 


\section{Introduction}

\section{Thai Canal: a new agenda in world trade}

The construction of Thai Canal / Kra Canal / Kra Isthmus Canal has been discussed among journalist, the academia and politicians since the late 1600 's. This canal is planning to connect the Gulf of Thailand with the Andaman Sea across Southern Thailand. The aim of this canal is comparable to Suez and Panama Canal constructions which to decrease the hours of navigation of shipping lines during cargo transactions from one point to another. In that case, this waterway will be an alternative route instead of Straits of Malacca. The Strait of Malacca connects the Pacific Ocean to the Indian Ocean which becomes a substantial channel for economic advancement due to the political advantageous. It is estimated that 50,000 thousands ships, carrying as much as one-quarter of the world commerce and half of the world's oil, pass through the Straits of Malacca and Singapore each year (Anor et al., 2012). This indicates the important of Malacca strait for the navigation of various types of ships including tankers, container, bulk carrier, barges and passenger vessels especially to connect the trade community and become a connecting waterway between east and west market in the globe.

A Memorandum of Understanding has been signed between Beijing with the China-Thailand Kra Infrastructure Investment and Development Company and Asia Union Group in Guangzhou in 2015. This has become a main agenda for the development of new trade passage in this region (Pookaman, 2018). The navigation vulnerability, navigational saturation, shallowness of straits of Malacca, preparation to accommodate larger vessels, an additional plan for strengthening Thai national security have become the motivation to build this artificial waterway. The idea of Thai Canal was a very ancient plan by the Thai government. A cutting through the Isthmus, at its narrowest barely forty miles across would be an obvious saving of time on the run between India and China, by eliminating the long navigation through the Malacca Straits (Kiernan, 1956). The constructing of Thai Canal had been planned a long time ago however, the construction unable to be executed due to the limited technology advancement and insufficient capital in Thailand (Vagabond, 2016). Figure 1 shows Straits Malacca which connecting east and west market in the maritime trade (Black Lane in Figure 1). Red Lane in the same figure is the new routes (Thai Canal) that will be penetrated through Gulf of Siam and Malacca strait. Further, the existence of this new canal will reduce the distance between east and west, avoid the congestions on foreland activities in Singapore, Port of Tanjung Pelepas and Port Klang as well as preventing shipping lines from passing through few dangerous chocking points at Strait of Malacca (Rusli, 2012).

Figure 1: Existing and new trade route to/from east and west

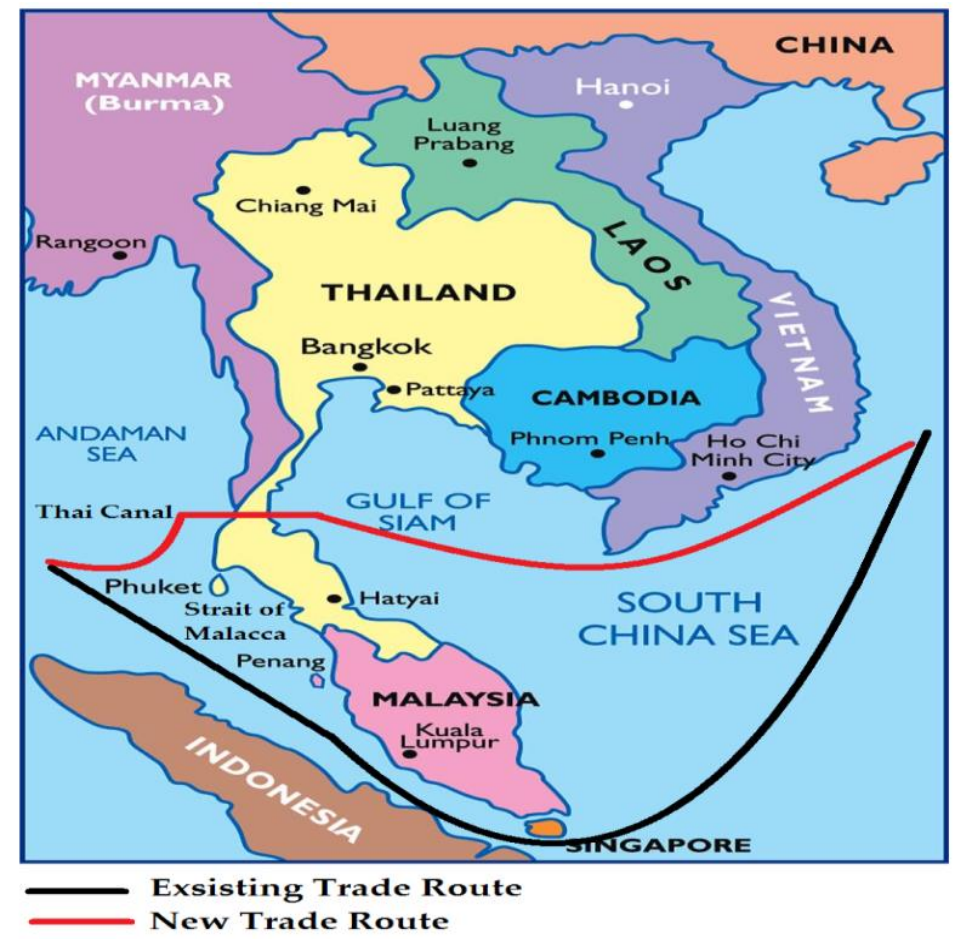

Source: Authors 
The idea of the construction of this new canal is not new because it was suggested in early 1677 by the King Narai to French government to build a waterway to connect Songkhla with Myanmar. However, the proposal has been discarded as impractical with technological advancement which still at the infant stage (Vagabond, 2016). Recently, the intention of China to invest in order to resume the construction of Thai Canal has built a new hope in order to execute this long planned agenda. The development of this canal may give massive impact especially to Malaysia, Brunei, Singapore and Indonesia especially on transportation system and environment (Tennenbaum, 2014). Hence, this paper is significant to predict the advantages and disadvantages of Thai Canal to Malaysia especially on trade and infrastructure.

Owing to the limited academic research on the implication of Thai Canal on Malaysian seaport system, this paper investigates the effects of this waterway on Malaysian trade and infrastructure performance. This paper, through face to face interviews with experts who are associated with Malaysian seaport system, provides a clear picture of the consequences that might occur due to the emergence of this new waterway between Malaysia and Thailand. The structure of this paper organised as follows. Section 2 distinguishes maritime canal and straits as well as revealing importance of major canals and straits in the trading world. Section 3 explains on the methodological application which has been employed in this paper. Results and discussions are presented in Section 4, 5 and 6 subsequently. Section 7 discusses the functionality of dry ports in the Thai Canal network and concluding remark is given in Section 8.

\section{Maritime trade waterways: canals or straits?}

In general, maritime canals and straits play an important role during freight transportation around the globe. These two routes have become an alternative for the maritime transporter to reduce their navigation duration, fuel cost and fuel consumption reduction, improving on-time delivery as well as preserving effective performance besides navigating in the wild and unpredictable condition of the ocean. Technically, straits and canal possesses their own significant criteria that clearly distinguish both of these waterways. A strait is a narrow body of water that connects two larger bodies of water however, canal is an artificial waterway constructed to allow the passage of boats or ships inland or to convey water for irrigation (Oxford Dictionary, 2018). Canal and straits are two alternatives routes that developed by mankind (canal) and emerged due to the geographical reason (straits) that have been utilised for the benefits of trades. In this paper, the focus will be given to manmade canal in Thailand by comparing and revealing the advantageous and disadvantageous provided to Malaysian trade and infrastructure. The following section providing explanations on straits and canals that actively is being used in the world of trade.

\subsection{Straits of Malacca: revealing the current status}

Malacca Straits is an original and important route that connects Indian Ocean to South China Sea. It links major economic nations such as Middle East, China, Japan and South Korea to western market. The parameter of the straits is 65 kilometres wide and 800 kilometres in length of shipping waterways, creating one of the world's traffic chokepoints. There are more than 200 vessels passing this Malacca Straits in a daily basis, including 40-50 oil tankers carrying an estimated 15 to 16 million barrels of oil, might transit to and from Asian seaports (Ba, 2018). This is the reason that the Straits of Malacca become one of important waterways in the world. Even Malaysia and Singapore garner enormous advantages from Straits of Malacca to enhance and develop their economic performance by creating a lot of job opportunities for local and international human factors through the seaports and seaport centric logistics business along the straits (Hayashi, 2002).

Along the Straits of Malacca, maritime industry especially related to seaport growing efficiently especially in Selangor (Port Klang), Penang (Penang Port), Johor (Port of Tanjung Pelepas and Johor Port) and Malacca (Port of Tanjung Langsat and Port of Kuala Linggi). The Straits of Malacca vindicate its geopolitical position is one of important factor that contribute to the competitiveness of seaports in the world sea lanes. These seaports which located along this straits become significant for shipping, labour migration and knowledge exchange especially between neighbouring countries (Darit, 2011).

A vague observation depicts that construction of Thai Canal expected to reduce number of vessels passing through Straits of Malacca. However, Straits of Malacca will still remain strategically salient for trade between the Persian Gulf and Indonesia or Australia especially for containerships (Panda, 2013). Besides, the construction of Thai Canal indirectly benefits Singapore and Malaysia by triggering an acceleration of economic development and 
trade in the entire region (Tennenbaum, 2014). Obviously, Thai Canal would affect Port Klang performance but, it would assist to develop the country's north region of Peninsular Malaysia such as Penang, Kedah and Kelantan due to geographical advantages.

Containerised trade is important to measure the performance of container seaports. In Malaysia, Port Klang and Port Tanjung Pelepas are ranked top 20 containers in the world (World Shipping Council, 2018). Though, the performance of Port Klang and Port Tanjung Pelepas will be affected due to the existence of this new waterway as well as diverting the trade focus towards northern region and east coast regions of peninsular Malaysia. The construction of Thai Canal affects major seaports performance and reduces the demand on Port Klang and Port Tanjung Pelepas among their clients. As inland component has become a major determinant for seaport competitiveness, the migration of cargo from central towards northern region can be overcome if all those seaport progressing well by improving their integration with inland territory.

\subsection{Thai Canal: emerging trade link between Thailand and Malaysia}

The plan to construct Thai Canal by Thailand government is not a new agenda. It has been discussed a long time ago, but because of certain reasons (cost and facilities), the construction of the Thai Canal unable to be executed. However, if the canal has been built the estimated time duration to cross Indian Ocean to South China Sea may reduce transportation cost at the same time reducing oil consumption compared to inefficiency gained in the same perspectives by using Straits of Malacca. Besides, vessels can avoid heavy traffic at Straits of Malacca and can reduce number of accident of ship at the straits (Jeevan, 2016). By using Thai Canal, vessels can reduce their journey for 2-3 days (instead of using Malacca straits). Further, Kra Canal may reduce 4-5 days instead of navigating via Sunda Straits and finally 6-7 days can be reduced via Kra Canal instead of using Lombok strait in Indonesia (Refer to figure 2.Concern has been aroused that Thai Canal will not affecting Thai economy and significantly not providing return benefits due to the attractiveness possessed by primary seaports in Malaysian as well as in Singapore (Thongsin, 2002). This situation confirmed that the attractiveness owned by seaports reducing and preventing from become less attractive due to any rivalry arose via inter or intra regions competitors.

In contrast, the development of Thai Canal is possible to contribute positive advantage to Thailand. For example, Thai government will develop transportation infrastructure to allow for greater connectivity, substantial access to trade routes and increase the attractiveness of investors to invest in their region. Besides, Thai government may generate revenue from activities related to Thai Canal such navigations, toll fees, tariff, space allocations and value-added services (Sulong, 2012). On the other hand, the construction of Thai Canal might provide negative impact to Malaysia. This is because Bangkok will have the advantage on the canal because shippers will prefer to navigate through this new waterway for a shorter and faster journey from east to west and vice-versa (Chen and Kumasai, 2016). However, the construction of Thai Canal will be not a perfect choice for shipping lines because the toll fee for passing through the Thai Canal in addition with other charges which will affecting freight chargers at the point of destination. Hence, shippers will prefer to utilise Straits of Malacca as their preferable route due to its nature of free toll passageway. Constructions of Thai Canal actually providing mixed impacts to Malaysia. Negative impacts of the canal to Malaysia are reduce the ship traffic in Straits of Malacca, reduce ship call at local ports, decrease containers trade at local ports and change in trade and economic development of pattern. On the other hand, this canal improves overall security and navigational in Straits of Malacca, improve capacity to cater increasing traffic volume, enlarge our manufacturing base and international trade, promote regional trade and hub and improve our port competitiveness (Khalid, 2006). 


\section{Figure 2: Kra canal in Malaysian trade radius}

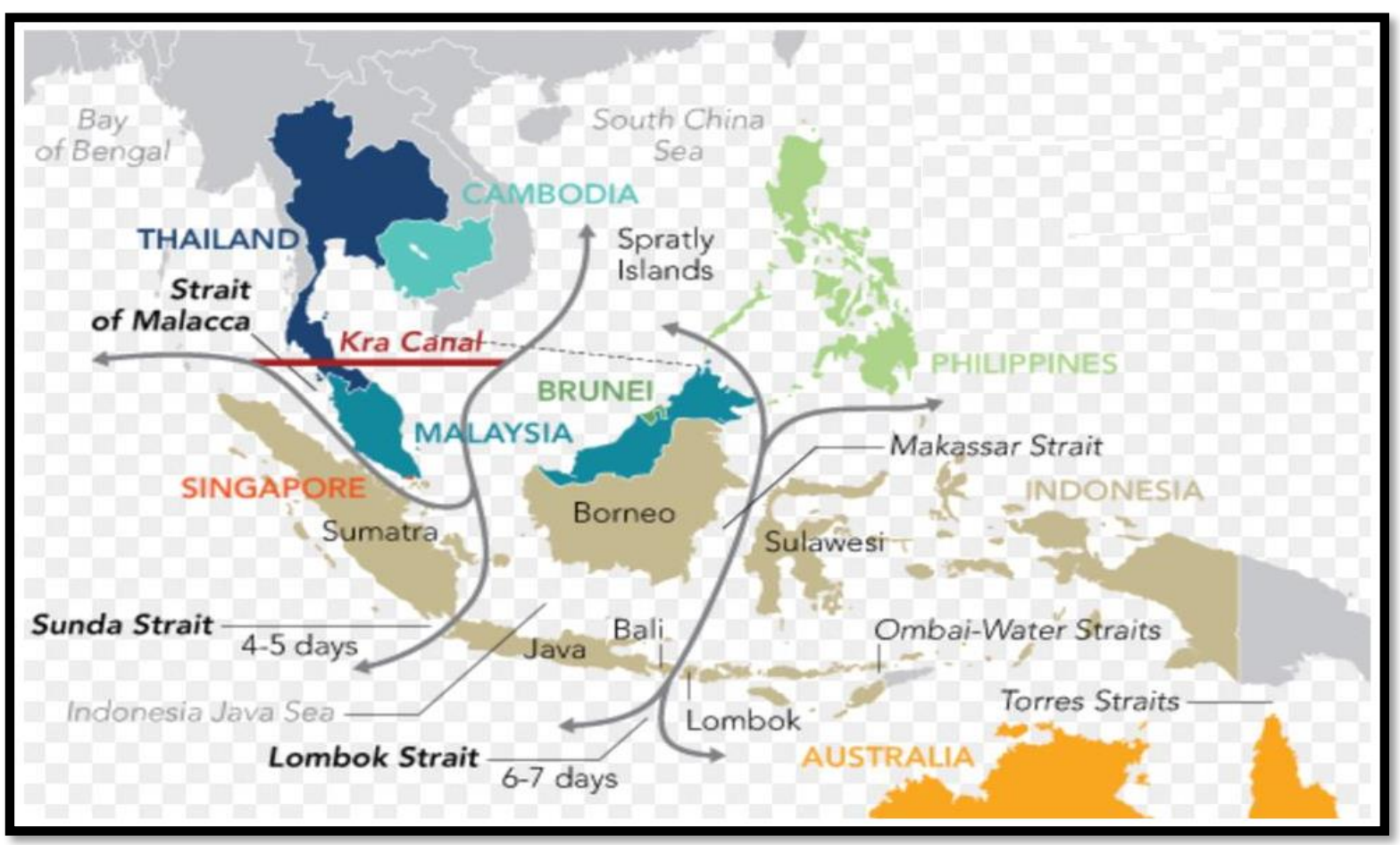

Source: Adapted from Asia Times (2018)

\subsection{The Panama Canal, Central America}

Panama Canal is about 80 kilometres long which flow from the Atlantic at Cristobal to the Pacific at Balboa. It has been in the operation since August 1914 and recording approximately 13 to 14 thousand vessels (300 million tons of cargo) navigate through this waterway every year. About 4 per cent of world borne trade especially from China and USA are moving through this waterway heading to their respective destination around the globe (David and Piala, 2016). Panama Canal is an example of manmade canal to make a journey become shorter that connecting the Pacific and Atlantic Ocean. The construction of Panama Canal contributes to a lot of changes especially on infrastructure and container trades to nearest region. The expansion of Panama Canal creates changes of economy impact due to investment in seaport expansion project and rise in cargo traffic import. Panama Canal has significant impacts on the global trade and on U.S ports and inland infrastructure. For example, the distance of navigation from Los Angeles to New York via Cape Horn in South America is about 23,982 kilometres. Conversely, the utilisation of Panama Canal reduces the total distance to 9,117 kilometres. This canal has save about 14,865 kilometres which has become a major advantage for the shipping line to reach the destination efficiently as per stated in their schedule. This is such a great situation that can be a guideline for Malaysia to be prepared on the construction of Thai Canal. For example, changes in transportation network such a rail network over time in response to the market need, the volume of trade and cargo flowing also increase rapidly in order to provide worldwide opportunity (Yu, 2015). In addition to that, intermodal modes especially rail linkages will be enhanced due to the increment on container trade. This canal assists many of U.S top 10 container seaports to reach their capacity target. Besides, it improves and upgrades connections to regional and national road and double deck rail network (Salin, 2010).

\subsection{The Suez Canal, Egypt}

Suez Canal is a vital passage that connects the Mediterranean Sea and Red Sea. It was opened for international navigation in 1869 with 193 kilometres long and about 310 metres of wide. It is the longest canal without locks in the world and is navigable 24 hours a day (David and Piala 2016). The planning of expanded of Suez Canal creates job opportunities and boost economy ravaged by years of political instability. The existence of Suez Canal helps to develop transportation hub nearby such as rail and road network. Besides, it also becomes a motivation for the 
growth of industrial area in this region (Tighe, 2015). Volume of trade passing through this canal significantly increasing from 5,579 in 1975 to 17,823 in 2015 (Kenawy, 2015) Suez Canal important for canal traffic, this canal represents more than $50 \%$ of volume of the market served. Furthermore, Suez Canal helps to increase quality of trade and transport related infrastructure. The expansion of Suez Canal contributes to the construction of six underground tunnels for the passage of vehicles by road and rail (Deandreis, 2015).

\begin{tabular}{|c|c|c|c|}
\hline Waterways & Straits of Malacca & Panama Canal & Suez Canal \\
\hline Connecting point & $\begin{array}{l}\text { Connects Indian Ocean and } \\
\text { South China Sea }\end{array}$ & $\begin{array}{l}\text { Connects Atlantic and the } \\
\text { Pacific }\end{array}$ & $\begin{array}{l}\text { Connects the } \\
\text { Mediterranean Sea and Red } \\
\text { Sea }\end{array}$ \\
\hline Parameters & $\begin{array}{l}65 \text { kilometre (wide) and } 800 \\
\text { kilometre (length) }\end{array}$ & $\begin{array}{l}320 \text { metre in length and } 33.53 \\
\text { metre in wide. }\end{array}$ & $\begin{array}{l}193 \text { kilometres length and } \\
\text { about } 310 \text { metres in wide }\end{array}$ \\
\hline *Vessels traffic & 73,000 vessels/year & 14,000 vessels/year & 17,823 vessels/year \\
\hline${ }^{*}$ Revenue generated & NA & $\$ 1.93$ billion & $\$ 5.3$ billion \\
\hline *Seaborne trade & $25 \%$ of global seaborne trade & $\begin{array}{l}\text { Almost } 4 \% \text { of global } \\
\text { seaborne trade }\end{array}$ & $\begin{array}{l}8 \% \text { of global seaborne } \\
\text { trade }\end{array}$ \\
\hline
\end{tabular}

Source: Authors *Based on 2016 \& 2017

A few years ago, Suez Canal has been closed for 6 days because of conflict between Egypt and Israel. The closure of Suez Canal gave a significant impact to the economy of the country. Trade and income decreased rapidly, container trade and transportation network at Suez Canal drop down and unable operate as usual (Feyrer, 2009). This situation shows on how important of the effective canal operation to the economy of the country. Comparisons between these canals and straits are depicts in Table 1.

\section{Methodological application and unit of analysis}

Thematic analysis has been employed in this research. Thematic analysis is defined as qualitative analytic method for identifying, analysing, and reporting pattern within data. This analysis helps to move from a broad reading of data toward discovering patterns framing a specific research question. The process of thematic analysis can be conducted by field diaries, audio recording historical data and transcript. A qualitative explorative design employing semi-structured in-depth interview with key players in Malaysian seaport system has been conducted. According to Broun and Clarke (2016), thematic analysis has been selected as a data analysis tool because it allows for flexibility and allows for detailed and complex description of data.

This analysis allows for flexibility for detailed and complex description of data. Further, the flexibility of this method may develop a deeper appreciation for the group or situation that had been researched (Komori, 2014). In this paper, face-to-face interview have been conducted with experts from four main agencies including Malaysian railway, Ministry of Transportation, Port Klang Authority and Malaysian Marine Department. Experts from different agencies had been approached to be interviewed and give an opinion about the impact of the Thai Canal on Malaysian Trade and Infrastructure.

During the interview session, the questions were design based on two main components which including trade and infrastructure in order to achieve the aim of the paper and to ensure the interview session is remain in the particular scope. This practice is important to ensure two main key features of interview session which including the interview should flow naturally and rich of information have been applied throughout the session (Alshenqeeti, 2014). The questions during the interview session were mainly based on their view or opinion on the construction of Thai canal (in general), their opinions on the implication of this canal on Malaysian container trade, the consequence of this canal on Malaysian connectivity (transportation system), changes that will be faced by seaports from the construction of this new canal in northern region of peninsular Malaysia (from trade and infrastructure perspectives), the advantages and disadvantages of this canal on Malaysian trade and infrastructure. 


\begin{tabular}{|c|c|c|c|c|}
\hline Organisation & $\begin{array}{l}\text { Number of } \\
\quad{ }^{*} \text { FIP }\end{array}$ & Designation of participant & $\begin{array}{c}\text { Duration of } \\
\text { interview } \\
\text { session }\end{array}$ & Identity code \\
\hline \multirow[t]{3}{*}{ Malaysian railway } & \multirow[t]{3}{*}{3} & Cargo Service Managers (I) & 55 minutes & FIP 1 \\
\hline & & Cargo Service Managers (II) & 45 minutes & FIP 2 \\
\hline & & Conventional service Managers & 35 minutes & FIP 3 \\
\hline $\begin{array}{l}\text { Ministry of } \\
\text { Transportation }\end{array}$ & 1 & Secretary of Maritime Division & 75 minutes & FIP 4 \\
\hline \multirow[t]{2}{*}{ Port Klang Authority } & \multirow[t]{2}{*}{2} & Senior Marine Officer I & 25 minutes & FIP 5 \\
\hline & & Senior Marine Officer II & 45 minutes & FIP 6 \\
\hline Malaysian Marine & 2 & Chief Assistant Director (I) & 65 minutes & FIP 7 \\
\hline Department & & Chief Assistant Director (II) & 45 minutes & FIP 8 \\
\hline
\end{tabular}

*Face to face interview participant (FIP)

\section{Result and discussion}

Eight respondents have been interviewed to analyse the implications of Thai Canal on Malaysia trade and infrastructure. The interview session took from 25 minutes to 75 minutes. Information of selected participants is illustrated in Table 2. During the interview session, these participants have provided many spectrums of opinions regarding the establishment of this waterway in northern Malaysia. For example, a participant from Malaysian Railway (FIP1) has mentioned that this development expected to provide enormous benefits to northern region of peninsular Malaysia and southern region of Thailand in terms of mutual economic progression, regional infrastructure enhancement and national trade growth. Secondly, the participant from Ministry of Transportation (FIP4) mentioned that the capacity of this canal is manage to provide magnificent impact on Thailand ecological changes as well as leaving significant impact towards Singapore trade. Further, the participant from Port Klang Authority (FIP6) have mentioned that the development of this canal will affecting peninsular Malaysia including Sabah, Sarawak and Borneo especially on trade transaction as well as the number of commercial vessels that will select these regions as their port of call. Although number of commercial vessel will be affected in Borneo, the importance for passenger cruise will be preserved via tourism industry due to the existence of beautiful islands in Borneo, Indonesia, east and west coast of peninsular Malaysia. Conversely, the attractions towards these regions are not limited to islands, in fact, culture, sceneries, food and leisure activities are substantial factors that attract tourist towards these regions.

In addition to that, the introductions of this new canal will deteriorate the important performance of Port Klang, Port of Tanjung Pelepas and Johor Port in peninsular Malaysia. A participant from Marine Department (FIP7) ensures that the opening of this new trade waterway in between Thailand and peninsular Malaysia may become a stepping stone for Kedah, Perlis and Penang (states in northern region of peninsular Malaysia) as well as Kelantan and (state in east coast region of peninsular Malaysia) for human capital development in maritime logistics industries. In that case, the development of homological smart cities (HSC) can be observed in these regions. This HSC manages to execute peer-to-peer strategies and a starting point for social, economic and cultural innovations which promoting a new vision for future of local communities (Caperna et al. 2018). By leveraging the new waterway, local assets and new resources, they trigger community revival which affecting social network, regional development and human capital establishment.

Further, according to (FIP8), the opening of this new gate, the trade between east and west may generate the emergence of seaport tourism as new cluster in Malaysian and Thai maritime sector. The comment from this particular participant is aligned with Jeevan et al. (2017a). These authors have emphasised that four main components including cruise activities, support from intra-region and inter-region economic corridors as well as the evolution of seaport regionalisation provide additional capacity of Malaysian seaport in order to be hub for seaport tourism. Hence, the potential of Thai Canal may rejuvenate the establishment of intra-regional economic corridors and become an added advantage to northern region of Malaysia as a hub for seaport tourism. 


\section{Implications of Thai Canal on Malaysian trade system}

Based on interview sessions, about 68.4 per cent of codes generated via thematic analysis show that most of the repercussions that will be generated are channelled towards trade system and followed by the implications on infrastructures. According to (FIP1), the development of this new trade channel will transform the function of Padang Besar (existing dry port terminal) as a main cargo terminal in the northern region. Furthermore, the emergence of this new canal provides high possibility to reduce the competition between Lat Krabang inland container depot in Thailand with Malaysian Padang Besar Cargo Terminal (PBCT). Currently, Lat Krabang inland container depot faced significant time lost during freight transportation to Laem Chabang seaport due to congestions the far distant to/from Bangkok seaport also affecting the competitiveness of this terminal. Currently the government of Thailand encouraged cheaper transport costs either by train or road to avoid heavy competition with Padang Besar Cargo Terminal. Frequent train services with double tracks, shorter transit time, short loading time onto wagons as well as the arrangement of container arranged as planned are important parameters which expected to provide a strategic advantage to the Lat Krabang inland container depot. Hence, the development of this new canal, the competition between these two inland nodes will be reduced and cooperating strategy will be emphasised in order to cater the trade market provided in this new canal. This cooperating strategy will be a new agenda between them in order to provide sufficient volume of cargo to and from Bangkok seaport (for Thailand) and Penang Port (for Malaysia).

Laem Chabang and Hatyai will be a catchment zone for southern region while Pengkalan Kubor, Bukit Kayu Hitam, Padang Besar, Prai, Mak Mandin and Kulim will be an important cargo catchment zone for northern region in peninsular Malaysia. Those catchment zone in Malaysia are supported by the existence of rail, road and bridge linkages within the states and between nations (see Figure 3). The existence of those catchment zones with support of multimodal transportation and superstructure facilities determine the flow of cargo within and between nations are moving without flaws including delays due to congestions and preventing centralisation of cargo in certain areas in the regions which causing imbalance regional development. However, limited access of rail linkages within and between regions clearly shown in Figure 3 and the development of this new waterway is expected to motivate policy makers to actively involved and permit freight rail network development throughout the nation. It is important to reduce over dependency on road freight transportation, energise new structure in Malaysian freight transportation system and involving the participation of dry ports as a key component in the freight network.

Secondly, the emergence of this new trade route between east and west will affecting the container volume at Malaysian primary seaports including Port Klang and Johor seaport. This statement has been supported by a quote from (FIP2) by saying "The development of Thai Canal will reduce the cargo volume in Port Klang and Johor Port. Conversely, it will enhance the throughput in Penang Port". This indicates that the appearance of Thai Canal will be a great advantage for Penang Port and a major threat for Port Klang and Johor Port. This participant emphasise that the transformation of Penang Port as nation's hub port can be witnessed due to the development of this canal. In addition to that, a reply from (FIP5) indicates that the function of Port Klang will be decentralised and prioritising the demand for local merchants instead of international traders. The new role of Penang Port as international hub will be outpaced by the regional-based functionality of Port Klang. Hence, this participant added that a massive overcapacity issue will occur at Port Klang and even at Johor Port if this situation prolonged. As a consequence, there will be a possibility whereby Port Klang and Johor Port will be dissolved as significant nodes in the Malaysian seaport system.

On the other hand, (FIP4) from Ministry of Transportation declared that there will be inconsistency of cargo volume in dry ports in southern and central region compared to northern region of peninsular Malaysia. For example, this participant has emphasised that volume of container at Nilai Inland Port will be decreased whereby most of the cargo will be centralised at Padang Based or northern region. This participant also added that the Kuantan will expand towards as an industrial hub seaport. This situation shows that east coast peninsular Malaysian with the support from Malaysia-China Kuantan Industrial Park (MCKIP), East Coast Rail Link (ECRL) and Kuantan Waterfront Resort City (KWRC) will be attractive to investors and traders from Eastern Asia. 
Figure 3: Trade facilities in northern region peninsular Malaysia

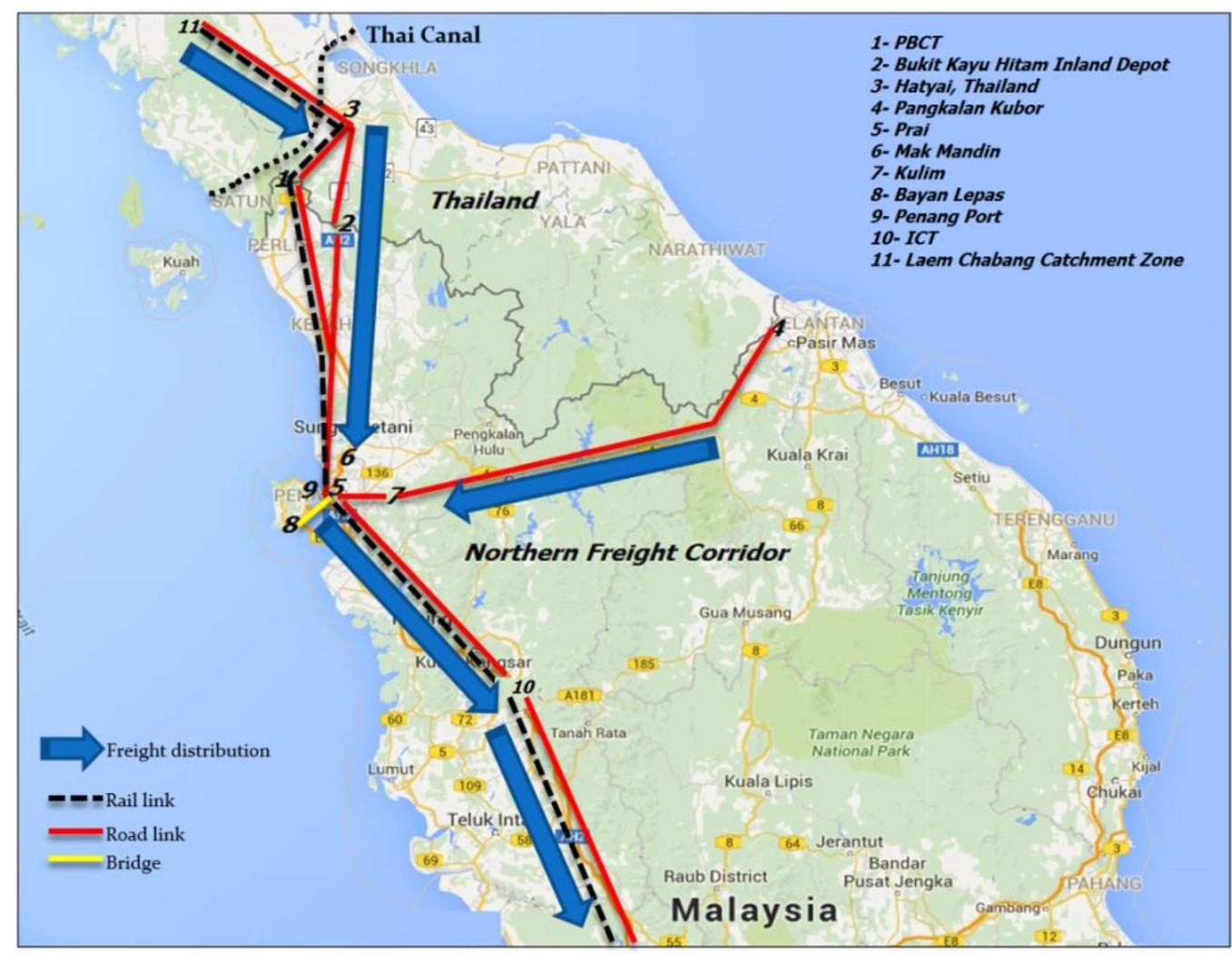

Source: Adapted from Jeevan (2017c)

A participant from Ministry of Transportation (FIP4) declared that the construction of this new canal will generate an equal economic development in peninsular Malaysia. Currently the economic development is skewed towards central and southern region. Conversely, the emergence of this waterway will boost the development of new inland terminals, new rail linkage for freight transportations, migration of customs and immigration personnel to inland as well as investment of shipping lines in inland.

\section{Implications of Thai Canal on Malaysian infrastructure}

Besides causing implication on trade system, the construction of Thai Canal provides significant implications on infrastructure in peninsular Malaysia. According to (FIP1 and FIP2), enhancement of cargo volume in peninsular Malaysia will increase the demand on road as well as rail transport network. Currently the proportion of rail and road in freight transportation is about 2:98 (Jeevan et al. 2017b). These participants believe that there will significant demands on rail freight transportation which will increase the demand on rail transportation substantially. Malaysia is one of the countries which have a significant linkage for road network among ASEAN country. Road system in Malaysia already connected with every state in peninsular Malaysia, either from northern to south or east to south. The road transport facility supported by expressway from north to south of peninsular Malaysia for fast and efficient fright transportation. However, rail transportation remains underutilised due to their outdated gauges, limited intra-state railway connectivity and limited capacity to handle maximum volume of cargo from one destination to another.

Thai canal will cause the rail and road system highly utilised especially for northern and east coast peninsular Malaysia. For short distance, hauliers will be an option to stakeholders and for long distance including inter-state freight transportation rail will become the appropriate option for the traders. The development of new linkages of rail and road network that connect to and from Penang Port might be appear directly from Kuantan to this particular seaport. In addition to that, the capacity of Penang seaport might be expended from its original size to larger size as a preparation to accommodate the increasing number of containers. For example, the capacity of Penang port in 1994, 2005, 2008, is 230,000 TEUs, 770, 000 TEUs, 1 million TEUs respectively and 2 million TEUs 
in 2012 and 2017 subsequently (PPC 2018). Due to the opening of this new canal, the capacity of this seaport is expected to grow in order to accommodate high volume of cargo from this canal, neighbouring countries as well as from regional market.

In order to ensure the movement of the cargo is smooth and efficient, the size of the road at east coast need to be develop and upgrade the state roads towards highway to connect east and west Malaysia effectively. Moreover, the freighting time will be reduced if the road linkages from northern region to east coast have been upgraded. For example, utilising this Thai Canal which well equipped with supporting trade facilities, the distance for voyage from east to west through this canal for cargo ships can be reduced up to 1,200 kilometres with $\$ 28$ billion of cost reduction compared to navigate across South China Sea and Malacca straits (Panyaarvudh, 2018). This situation indicates that this new opening provide significant implication on cost and time duration especially for cargo delivery from point of origin to point of destination. Further, the significant reduction in cost and time influence the price of cargo at the final destination which will improve the competitiveness of the goods in among the clients. Likewise, the extension of inland network to connect east and west coast market will become a stepping stone to connect cross border market including Singapore. Therefore, two main linkages (two-way traffic) will be established in east coast peninsular; Kuantan-Central region-Penang Port- Thailand and Kuantan-Johor-Singapore (see Figure 4).

The possibility to utilise inland transport network and reduce the dependency on ocean transportation will be achieved. Furthermore, the development of inland transport network will be aligning with the new canal and therefore, the trade on Thai canal will be coordinated and incorporated with this inland transportation network for maximum efficiency and preserve the competitiveness of the seaports as indicated in Figure 4. In general, PTP, Port Klang and Penang Port are categorised as transhipment seaports. However, margin for transhipment containers in PTP is significantly higher than other seaports. This situation indicates that the performance of Malaysian seaports scarcely to be affected due to the presence of this waterway. Technically, shipping lines both from east or west which have planned to deliver their cargo for transit in Malaysia will prefer to stick with their original plan rather than using this waterway and proceed to deliver the respective cargo to the port of destination. Again, the nature of the seaports of Malaysia as transhipment seaports as well as the geospatial factors which have determine to prolong the demand for these seaports by shipping lines.

Figure 4: Inland detour connecting east and west coast Malaysia

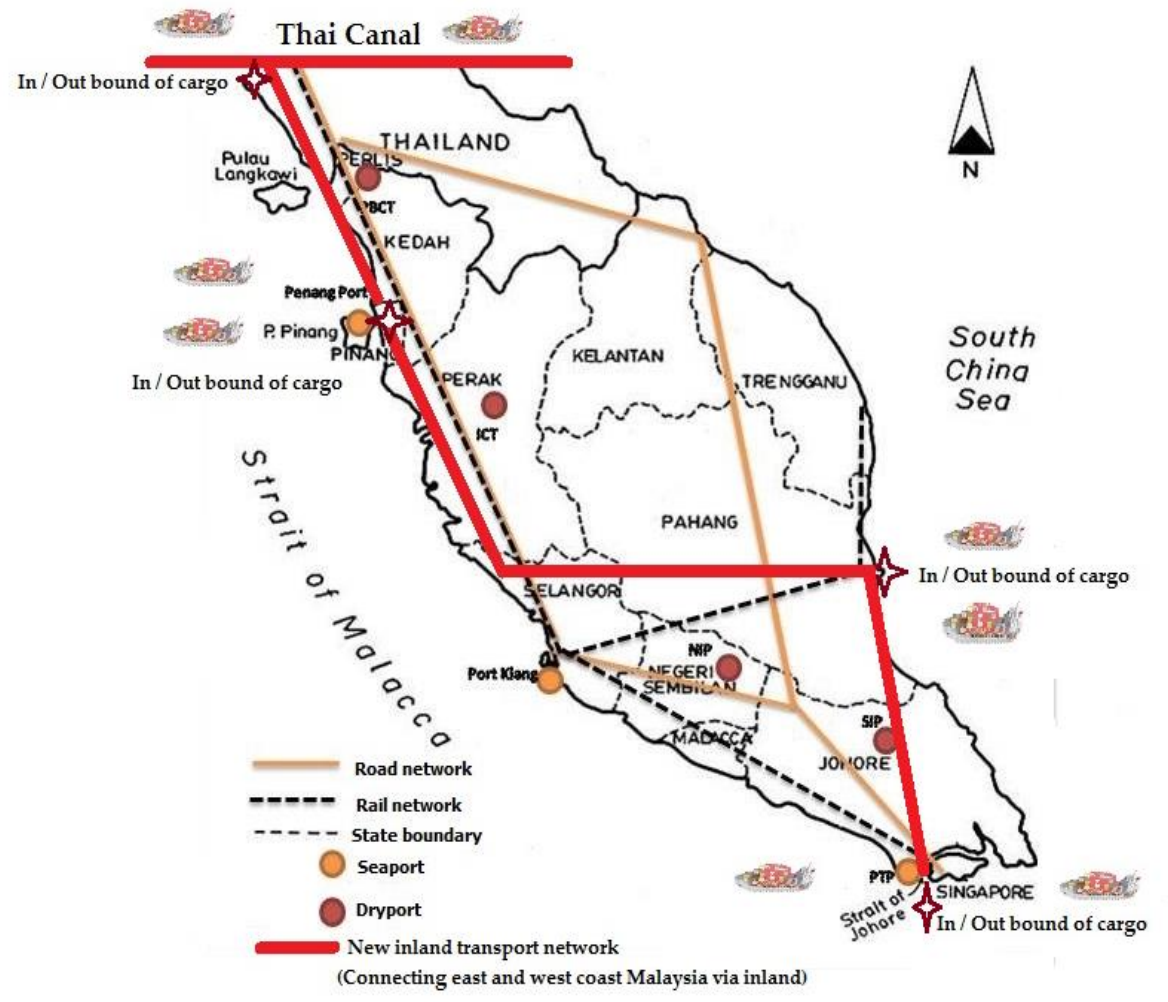

Source: Authors 


\section{Transformation of dry ports functionality in the Thai Canal network}

According to Jeevan et al. (2017a), the function of Malaysian dry ports are focusing on four main purposes including transport function (connecting seaports and manufacturing inlands and facilitate door-to-door services for containers delivered to or picked up from seaports) logistic function (warehousing, storage and $\mathrm{de} /$ consolidation activities), administration function (customs clearance, immigration and police inspection for domestic and international containers distribution) and a value adding function (assorting, mixing, blending, packaging and repackaging, labelling and relabeling, offering tailored services beyond the standard offer, exporting packaging for transport requirements, offering disposal services, container weighing and services, and giving product advice to consignees and distriparks). In that case, the presence of this new waterway will utilise all those functions in order to improve cargo transaction via inland. Further, this situation will ensure that attractiveness of dry ports will be improved parallel with seaports especially in northern region.

Firstly, (FIP1, FIP2 and FIP7) agree that some of foremost issues in Malaysian dry ports are low frequency or train movement, low capacity of train decks to carry high volume of containers, insufficient railway tracks and maximum utilisation of single mode transportation and no rail services in certain dry ports. Therefore, introduction of new waterway in between Thailand and Malaysia dramatically will enhance the usage of multimodalism especially equal demand on rail and road freight transportation between Thailand-MalaysiaSingapore. As Thailand and Singapore are main trading partners from South East Asia regions to Malaysia (see Table 3), the existence of this waterway may double or triple fold the trade volume between Malaysia and Singapore as evidence from the utilisation of inland transportation. This situation might be slightly different between Malaysia and Thailand because the access to cross the waterway via inland will be limited due to that additional investment are required to build a connecting bridge for road and rail freight transportation between these two nations.

\begin{tabular}{llll}
\multicolumn{2}{l}{ Table 3: Malaysian } & primary trading nations & \\
\hline Nations & Malaysian exports (USD) & Nations & Malaysian imports (USD) \\
\hline Singapore & $\$ 31.6$ billion $(14.5 \%)$ & China & $\$ 38.3$ billion $(19.6 \%)$ \\
China & $\$ 29.4$ billion $(13.5 \%)$ & Singapore & $\$ 21.6$ billion $(11.1 \%)$ \\
United States & $\$ 20.7$ billion $(9.5 \%)$ & United States & $\$ 16.1$ billion $(8.3 \%)$ \\
Japan & $\$ 17.4$ billion $(8 \%)$ & Japan & $\$ 14.8$ billion $(7.6 \%)$ \\
Thailand & $\$ 11.8$ billion $(5.4 \%)$ & Taiwan & $\$ 12.8$ billion $(6.5 \%)$ \\
Hong Kong & $\$ 11.2$ billion $(5.1 \%)$ & Thailand & $\$ 11.2$ billion $(5.7 \%)$ \\
Indonesia & $\$ 8.1$ billion $(3.7 \%)$ & Indonesia & $\$ 8.8$ billion $(4.5 \%)$ \\
India & $\$ 8$ billion $(3.7 \%)$ & South Korea & $\$ 8.5$ billion $(4.3 \%)$ \\
Australia & $\$ 7.5$ billion $(3.5 \%)$ & India & $\$ 6.3$ billion $(3.2 \%)$ \\
South Korea & $\$ 6.7$ billion $(3.1 \%)$ & Germany & $\$ 6.1$ billion $(3.1 \%)$ \\
Vietnam & $\$ 6.4$ billion $(3 \%)$ & Vietnam & $\$ 5.3$ billion $(2.7 \%)$ \\
\hline
\end{tabular}

Source: Adapted from Workman (2018)

Secondly, the construction of this waterway enhances the cooperation between seaports and dry ports (FIP5). Currently, these two nodes are competing each other to increase the volume of containers in each node although seaports are the main investors in dry ports. Hence, this Thai Canal becomes a pushing factor for seaport to cooperate with dry ports to increase their capacity during the cargo transactions across the borders. In addition to that, this will open the opportunity for shipping lines to invest in dry ports instead of seaports due to their popularity and demand among their clients in inland. Then, the utilisation of dry ports especially in southern region will be increasing due to the potential development of multimodal transportation between ThailandMalaysia-Singapore.

For transhipment containers, seaports are regularly requested to act as buffers and consistently accommodate the request of their clients concerning last minute schedule alterations such as delays, break of calls and requirements for additional yard storage (Notteboom 2006). Conversely, any seaports which are unable to provide this flexible operational procedure will lose their competitive edge and create a negative identity for the entire supply chain (Acciaro and McKinnon 2013). Previously, it has been mentioned that the nature of Malaysian seaports as transhipment hub hardly affected due to the construction of this new waterway. In addition to this argument, the function of dry ports also required to ensure that seaports sustain with their current role. For 
example, containers need to be 'pushed' immediately to inland in order to reduce the chargers that will be imposed to these containers at seaports. In comparison, the chargers that be levied at seaports are comparatively expensive (to container that remain in seaports) compared to chargers being implemented in the dry ports. Therefore, the transhipment seaport operators are encouraged to infuse dry ports in the daily operation to reduce the charges towards containers which have been kept in these particular inland terminals. This low charge will attract additional clients to this seaport as well as improving their competitiveness in comparison with other seaports which provide identical forms of services. Yet again, the performance of Malaysian seaports will be not affected due to the development of new waterway at their neighbouring region.

Research by Rodrigue and Notteboom (2012) indicated that transhipment containers included foreland containers and cross inland border containers. This transhipment pattern is normally found near country borders alongside value adding logistics activities. For example, dry ports in western China perform transhipment activities to main Chinese seaports by distributing and consolidating containers to and from Russia, Central Asia and South Asia (Beresford et al. 2012). A dry port can assist a seaport in tackling issues such as last-minute changes in shipping lines, requirements for additional space for transhipment containers and bringing flexibility to seaport operations. The location of Malaysian close to Singapore, Thailand, Indonesia, Philippines as well as Brunei required Malaysia to maintain their role as transhipment seaport to ease the de/consolidation, re/distributing and transit containers to the respective regions effectively. Based on Henttu and Multaharju (2011), the cost for transhipment handling solely at the seaport is more expensive than that incorporated within an inland terminal. Thus, the engagement of dry ports in seaport transhipment operations reduces transhipment costs, increase the volume of transhipment containers and in this case, the demand for these seaports keep accelerating despite the changes in the seaport system due to the existence of a new waterway in Thailand.

On the other hand, the utilisation of inland terminals due to existence of Thai Canal produces some negative implications in inland (FIP4). For example, traffic congestion in selected regions including central and northern region will be significant due to the limited capacity of railway track and limited inter-state connectivity. Then, the intention to utilise single transport mode (road) for fast and cost-effective delivery generates pollution and over utilisation of road facilities. This indicates that the existence of dry ports to assist the client in these three respective nations will provide mixed implications to the clients. Unbalanced economic planning on the east cost of peninsular Malaysia and in some areas in the northern and southern regions have caused some dry ports in the Malaysian container seaport system to remain underutilised (FIP 2; Jeevan et al. 2015). Therefore, all components in the freight system are required to well integrate through dry ports in order to open a new paradigm for the Malaysian container system to use, utilise and manage these opportunities for current and future development.

\section{Conclusion and implications}

This study explores the impact of Thai Canal on Malaysian trade and infrastructure and further looking into the transformation of dry ports towards the existence of this new waterway. The outcome indicates that the impact of this canal on Malaysian trade will be high demand for services provided by inland terminals, improvement of cargo volume in northern region seaport system as well as enhancing equal regional development in all regions especially in peninsular Malaysia. On the other hand, Thai Canal might reduce the demand for Port Klang since major transaction will be transferred to Penang Port. Decentralisation of seaport function will be witnessed at Port Klang and PTP as well as Johor Port due to the inconsistence of cargo volume in those seaports. Then, enhancement of multimodal facilities, increasing in seaport capacity to reduce freighting time and increasing the demand for inland terminals or dry ports are significant implication gained from the perspective of infrastructure. In addition to that, dry ports need to face some transformation in this situation. The research indicates that improvement in equal multimodal transportation and significant seaport and dry port cooperation will be observed in this new set-up.

Further, overdependence on single mode of transportation expected to produce pollution and congestion in inland. Effects of Thai Canal on environment and social are important to Malaysia as a preparation for any unpredicted issues in future and this issue are worth to be explored. This paper is focusing the view or perception from participants who attached to government agencies and there is no input from private sector and that will be the limitation of this paper. Although invitation has been made few times for this group of participants, busy schedule and other commitments have become main reason for them to participate. During conducting this research, some of participant have mentioned that 'the construction of this canal is a political agenda and impossible 
to be implemented'. This substantial view among the participant has become a major limitation to access significant information during the completion of this paper. Nevertheless, the nature of dynamism in maritime logistics is challenging and difficult to predict hence, substantial preparations are required. "It is not the strongest of the species that survive, nor the most intelligent, but the one most responsive"- Charles Darwin.

\section{Acknowledgements}

The anonymous Delphi participants are genially thanked for their essential contributions to the study.

\section{Appendix A. Supplementary material}

Supplementary data associated with this article can be found, in the online version, at https://jsdtl.sciview.net

\section{Funding}

The authors received no direct funding for this research.

\section{Citation information}

Jeevan, J., Salleh, N. H. M., \& Othman, M. R. (2018). Thai Canal and Malacca straits: Complementing or competing stratagem for trade development in South East Asia. Journal of Sustainable Development of Transport and Logistics, 3(2), 34-48. doi:10.14254/jsdtl.2018.3-2.2.

\section{References}

Acciaro, M., \& McKinnon, A. (2013). Efficient hinterland transport infrastructure and services for large container ports. International Transport Forum Discussion Paper.

Anor, N., Ahmad, Z., Abdullah, J., \& Hafizah, R. N. (2012). Road network system in Port Klang, Malaysia and impacts to travel patterns. Procedia-social and behavioral sciences, 35, 629-636.

Ba, A. D. (2018). Governing the Safety and Security of the Malacca Strait: The Nippon Foundation between States and Industry. Journal of Contemporary Asia, 48(2), 252-277.

Beeley Jr, R. R. (2009). The Erie Canal: A Founding of a Village, Early Industry, and a Century of Change.

Beresford, A., Pettit, S., Xu, Q., \& Williams, S. (2012). A study of dry port development in China. Maritime Economics \& Logistics, 14(1), 73-98.

Braun, V., Clarke, V., \& Weate, P. (2016). Using thematic analysis in sport and exercise research. Routledge handbook of qualitative research in sport and exercise, 191-205.

Caperna, A., Tracada, E., Minervino, G., Alatalo, E., \& Cerreta, M. (2019). Spatial and Economic Smart Strategies for the 21st-Century Metropolitan City of Naples. In Smart Metropolitan Regional Development (pp. 665-755). Springer, Singapore.

Chen, C. M., \& Kumagai, S. (2016). Economic impacts of the Kra Canal: An application of the automatic calculation of sea distances by a GIS (No. 568). Institute of Developing Economies, Japan External Trade Organization (JETRO).

Evers, H. D., \& Darit, S. (2011). Malaysian Maritime Potential and the Straits of Malacca. Roczniki Socjologii Morskiej, 20, 40-45.

Dávid, A. \& Piala, P. (2016). The strategic maritime canals and straits. 2, XI.

Deandreis, M., (2015). The New Suez Canal: Economic Impact on Mediterranean Maritime Trade. $1-26$.

Feyrer, J., (2009). The 1967 to 1975 closing of The Suez Canal as a Natural Experiment. Distance, Trade and Income, 2-15.

Hayashi, R., (2002). Cooperation between coastal state and User States in The Malacca and Singapore Straits, 20-22. 
Henttu, V. \& Multaharju, S. (2011). Transshipment costs of intermodal transport in Finnish context. In Tutkimusraportti Research Report Faculty of Technology Management. Department of Industrial Management, Lappeenranta University of Technology, Finland.

Alshenqeeti, H. (2014). Interviewing as a data collection method: A critical review. English Linguistics Research, 3(1), 39.

Jeevan, J., Othman, M.R., \& Zuha,. R. (2017a). Exploring the Prospect of Malaysian Seaports as a Hub for Seaport Tourism: A Dimension of Strategic Planning in Maritime Transportation, Proceedings of the 2017, Global Tourism Conference, Tourism Development \& Innovation: A Catalyst for Sustainable Environment \& Livelihood 19-22, July 2017, Kuala Terengganu, Malaysia.

Jeevan, J., Chen, S. L., \& Lee, E. S. (2015). The challenges of Malaysian dry ports development. The Asian Journal of Shipping and Logistics, 31(1), 109-134.

Jeevan, J., Chen, S. L., \& Cahoon, S. (2018). Determining the influential factors of dry port operations: worldwide experiences and empirical evidence from Malaysia. Maritime Economics \& Logistics, 20(3), 476-494.

Jeevan, J. (2017c). The role of Malaysian dry ports in the container seaport system. PhD thesis, University of Tasmania.

Jeevan, J, Chen, S.L., \& Pateman. H. (2016). Implications of One Belt One Road for Malaysian Connectivity to International Trade Routes, Proceedings of the "One Belt One Road" (OBOR) Conference, December 1-2, 2016, RMIT University, Melbourne Australia.

Kenawy, E.M., (2015). The expected economic effects of the new Suez Canal project in Egypt. European Journal of Academic Essays, 1(12), 13-22.

Khalid, N., (2006). Potential Effects on Malaysian Port and Shipping Sector. Proposed Kra Canal Project, 10-12.

Kiernan, V. G., (1956). The Kra Canal Projects of 1882-5: Anglo-French Rivalry in Siam and Malaya. The Kra Canal Projects of 1882-5: Anglo-French Rivalry in Siam and Malaya.

Komori, M. (2014). Thematic Analysis. Retrieved January 132017 from: http://designresearchtechniques.com/casestudies/thematic-analysis/.

Notteboom, T. E. (2006). The time factor in liner shipping services. Maritime Economics \& Logistics, 8(1), 19-39.

Oxford dictionary of English (2018). New York, USA, Oxford University Press.

Panda, A. (2013). How a Canal Could Transform Southeast Asia. 1 December.

Panyaarvudh, J. (2018). Mixed reactions to Kra Canal project. Retrieved May 31, 2018 from http://www.nationmultimedia.com/detail/national/30341668.

Pookaman, P. (2018). Thailand's Kra Canal: Economic and Geopolitical Implications. Asia Sentinal. Retrieved November 6, 2018 from https://www.asiasentinel.com/econ-business/thailand-kra-canal-economicgeopolitical-implications/.

PPC, (2018). Penang Port Commission: Background of Penang Port Commission. Retrieved March 13, 2018 from http://spppisms.blogspot.com.au.

Rodrigue, J. P., \& Notteboom, T. (2012). Dry ports in European and North American intermodal rail systems: Two of a kind?. Research in Transportation Business \& Management, 5, 4-15.

Rusli, M. H. M. (2012). Navigational hazards in international maritime chokepoints: A study of the Straits of Malacca and Singapore. Journal of International Studies, 8(47), 1-35.

Salin, D. L. (2010). Impact of Panama Canal Expansion on the US Intermodal System (No. 147032). United States Department of Agriculture, Agricultural Marketing Service, Transportation and Marketing Program.

S Schmidt, T. P. (2010). Financing Innovation: Infrastructure Development In New Haven, 1750-1850. Students Legal History Paper.

Sulong, R. S. (2013). The Kra Canal and Southeast Asian Relations. Journal of Current Southeast Asian Affairs, 31(4), 109-125.

Tennenbaum, J., (2014). Fact Sheet on Kra Canal Project in Thailand. November.

Thongsin, A. (2002). The Kra canal and Thai security (Doctoral dissertation, Monterey, California. Naval Postgraduate School). 
Tighe, K. M. (2015). Suez Canal, expansion could mean economic, political gain for Egypt's leader. Retrieved January 14, 2017 from http://www.usatoday.com/story/money/business/2015/08/04/suezcanalexpansion-means-economic-and-political-gains-egypt-al-sisi/31098143/.

Times Asian. (2018). Mischief in Malacca: The Long Reach of China's Atoll Bombers. Asian Times Holdings Limited.

Vagabond, F., (2016). The real threat to S'pore - construction of Thai's Kra Canal financed by China. The Independent, 2 October.

Wang, Y. (2012). Management of the Grand Canal and it's bid as a world cultural heritage site. Frontiers of Architectural Research, 1(1), 34-39.

Workman, D. (2018). Malaysia's Top Trading Partners. Retrieved June 10, 2018 from http://www.worldstopexports.com/malaysias-top-import-partners/.

World Shipping Council. (2018). World Shipping Report. Brussels, Belgium.

Yu, C. W. (2015). A Study of the Impacts of the Panama Canal Expansion on the US Northeast Ports and Strategy of the Port of Boston. International Journal of Business, Humanities and Technology, 1-6.

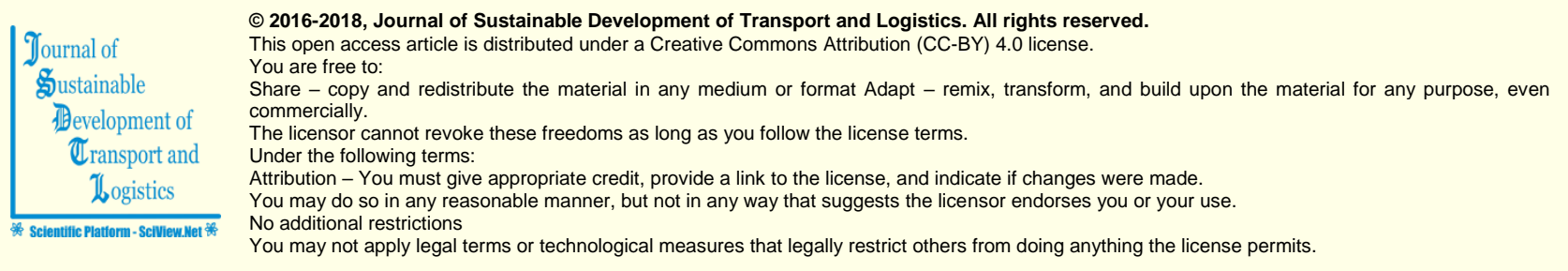

Journal of Sustainable Development of Transport and Logistics (ISSN: 2520-2979) is published by Scientific Publishing House "CSR", Poland, EU and Scientific Publishing House "SciView", Poland, EU

Publishing with JSDTL ensures:

- Immediate, universal access to your article on publication

- High visibility and discoverability via the JSDTL website

- Rapid publication

- Guaranteed legacy preservation of your article

- Discounts and waivers for authors in developing regions

Submit your manuscript to a JSDTL at https://jsdtl.sciview.net/ or submit.jsdtI@sciview.net 